\title{
Reductive dehydroxy coupling of 2-(hydroxymethyl)indenes to prepare ethano-bridged bis(2-indenyl) ansa-titanocenes
}

\author{
Hasan Palandoken, Justin K. Wyatt, Shawn R. Hitchcock , Marilyn M. Olmstead, \\ Michael H. Nantz
}

\begin{abstract}
New examples of ansa-titanocenes derived from 1,2-bis(2-indenyl)ethane have been prepared. The titanium-mediated reductive coupling of 2-(hydroxymethyl)indenes provided a convenient method for substrate dimerization. Alkyl substitution of the indene ring at $\mathrm{C}(3)$ improved the regioselectivity of the reductive coupling to provide the ethylene bis(2-indenyl)ansa-ligands in $29-62 \%$ yield.
\end{abstract}

\section{Introduction}

Chiral ansa-titanocenes have shown promise as homogeneous catalysts for various organic transformations including alkene epoxidation and hydrogenation [1]. The field has primarily featured ansa-titanocenes based on 1,2-bis(1-indenyl)ethane (1, Scheme 1, [2]). We have examined the reactivity of ansa-titanocenes derived from structurally isomeric 1,2-bis(2-indenyl)ethane (2) and observed that these systems also are capable of catalytic reactivity [3]. However, the synthesis of chiral bis(2-indenyl) ansa-titanocenes poses a greater synthetic challenge due to the intrinsic inactivity of the indenyl C(2) position [4]. Examination of the approaches used to synthesize ethano-bridged indenyl ansa-ligands illustrates the difference in ease of preparation (Scheme 1). Two straightforward strategies, depicted by the key retrosynthetic considerations $a$ and $b$, have been used to prepare 1,2-bis(1-indenyl)ethane and its derivatives. The direct alkylation of an indenyl anion with a 1,2-dihaloethane [5] (route $a$ ) and the metal-mediated coupling reaction of benzofulvene [6,7] (route $b$ )<smiles>C=C1C=Cc2ccccc21</smiles>

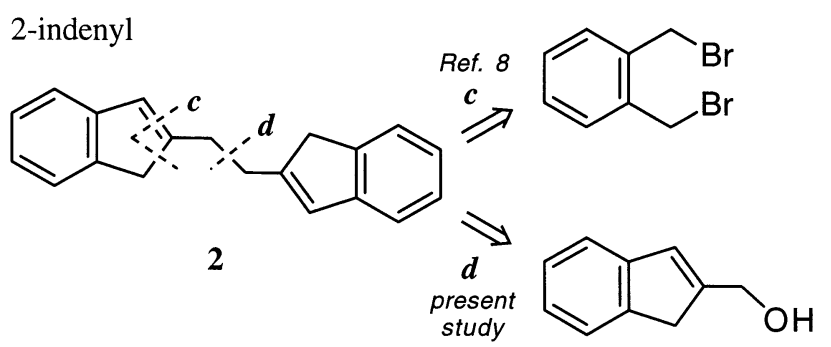

Scheme 1. General approaches to ethano-bridged bis(indenyl) systems. 
Table 1

Results of Ti-mediated coupling reactions (Eq. (1))

\begin{tabular}{llllc}
\hline Alcohol & $\mathrm{R}^{1}$ & $\mathrm{R}^{2}$ & Yield \% ${ }^{\mathrm{a}} \mathbf{( 4 + 5 )}$ & Ratio $^{\mathrm{b}} \mathbf{4 : 5}$ \\
\hline 3a & $\mathrm{H}$ & $\mathrm{H}$ & 36 & $1: 1$ \\
3b & $\mathrm{CH}_{3}$ & $\mathrm{H}$ & 36 & $1: 1$ \\
3c & $\mathrm{H}$ & $i-\mathrm{Bu}$ & 35 & $6: 1$ \\
3d & $\mathrm{H}$ & $i-\mathrm{Pr}$ & 33 & $8.3: 1$ \\
3e & $\mathrm{H}$ & $\mathrm{Bn}$ & 44 & Only $\mathbf{4 e}$ \\
3f & $\mathrm{H}$ & $\mathrm{SiMe}_{3}{ }^{\mathrm{c}}$ & 25 & Only $\mathbf{4 f}$ \\
$\mathbf{3 g}$ & $\mathrm{H}$ & $\mathrm{Ph}$ & 82 & $3.2: 1$ \\
\hline
\end{tabular}

a Isolated.

${ }^{\mathrm{b}}$ Determined by ${ }^{1} \mathrm{H}-\mathrm{NMR}$.

${ }^{\mathrm{c}} \mathrm{R}^{2}$ on $\mathrm{C}(1)$, see structure, Scheme 2.

have provided convenient access to bis(1-indenyl) ansaligands. These methods, however, cannot be employed with ease to obtain the 1,2-bis(2-indenyl)ethane framework due to the inactivity of the $\mathrm{C}(2)$ position.

To date, ethano-bridged 2-indenyl ansa-ligands have been prepared by tetraalkylation of 1,4-bis(phenylsulfonyl)butane using $o$-bis(halomethyl)benzenes (route $c$ ) [8]. Although expedient, the tetraalkylation approach delivers 2 in optimized yields of only $12-15 \%$. To improve the availability of bis(2-indenyl) ansa-ligands, we have examined a new synthesis based on retrosynthetic consideration $d$. We report herein on the reductive dehydroxy coupling of 2-(hydroxymethyl)indenes as a method for synthesis of ethano-bridged bis(2-indenyl) ligands.

\section{Results and discussion}

We became interested in 2-(hydroxymethyl)indene (3a) as a potentially useful precursor of 2-indenyl ansaligands due to the inherent symmetry of ethano-bridged ansa-metallocenes. Disconnection of the bridging carbons suggests a dimerization strategy. The low-valent titanium-mediated reductive coupling of allylic alcohols is known to be an effective means of alkyl dimerization [9]. Thus, we pursued the synthesis and reductive coupling of 2-indenyllic alcohols.

\subsection{Ligand syntheses}

Initially, we examined the reductive coupling reactions of 2-(hydroxymethyl)indene (3a) [10] and a methyl-substituted derivative, $\mathbf{3 b}$. Treatment of alcohol 3a with low-valent titanium [9a] in 1,2-dimethoxyethane afforded a 1:1 mixture of the desired coupling product 4a and the regioisomeric $\alpha$-coupling product $\mathbf{5 a}$ in $36 \%$ combined yield (Eq. (1), Table 1). The isolation of 5a was not unexpected since the formation of allylic radicals has been postulated to occur on thermal fragmentation of intermediate titanium (II) dialkoxide species [9a]. Diradical coupling of the incipient allylic radicals at either the terminal methylene carbon or indenyl methine carbon accounts for the formation of $\mathbf{4 a}$ and $\mathbf{5 a}$, respectively. Treatment of $\mathbf{3 b}$ under similar reaction conditions gave identical results, affording a 1:1 mixture of products $\mathbf{4 b}$ and $\mathbf{5 b}$ in $36 \%$ yield (Table 1).
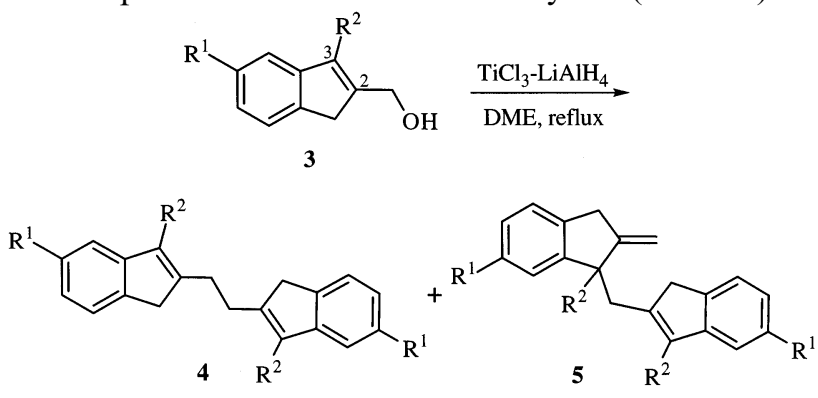

Substitution at $\mathrm{C}(3)$ was examined to minimize formation of the $\alpha$-coupling products 5 , a strategy that alters only the order of alkylation previously reported for synthesis of C(3)-substituted bis(2-indenyl) ansa-ligands [3]. Silyl protection of the hydroxymethyl group of 3a was followed by treatment with $n$-BuLi and addition of alkyl bromide to effect the alkylation (Scheme 2). Subsequent silyl group removal by treatment with tetrabutylammonium fluoride gave substituted indenes $\mathbf{3 c}-\mathbf{e}$ [11] in $30-74 \%$ overall yield.

Silylation of $\mathrm{C}(1)$ was accomplished by treatment of 3a with two equivalents of $n$-BuLi followed by quenching with excess TMS-Cl. Aqueous work-up and silica gel column chromatography was sufficient for $O$-silyl group removal and gave indene $3 \mathbf{f}$ in $97 \%$ yield.

Introduction of a phenyl group onto $\mathrm{C}(3)$ was accomplished by regioselective opening of an indenyl $\mathrm{C}(2)-\mathrm{C}(3)$ epoxide at the benzylic position. This approach was initiated by treatment of 6 with mCPBA in-
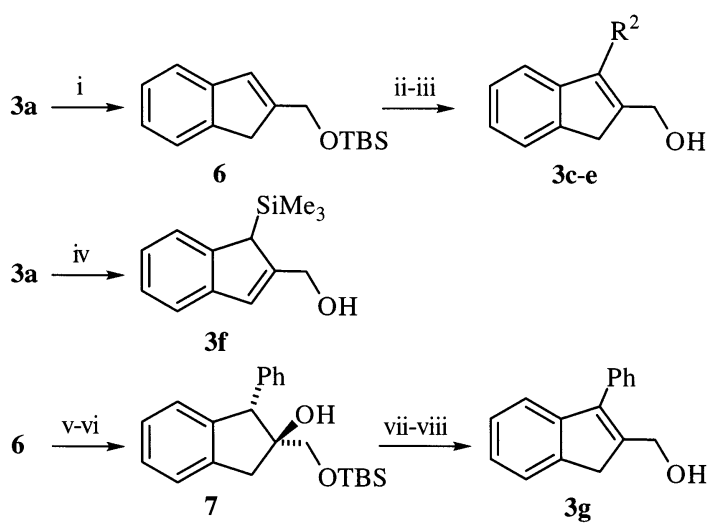

Scheme 2. Indene substitution, [i] tert-butyldimethylsilyl chloride, $\mathrm{Et}_{3} \mathrm{~N}, \mathrm{CH}_{2} \mathrm{Cl}_{2}$, cat. DMAP; [ii] (a) $n$-BuLi, THF, $-78^{\circ} \mathrm{C}$, (b) $\mathrm{R}^{2} \mathrm{Br}$, $55^{\circ} \mathrm{C}, 12 \mathrm{~h}$; [iii] TBAF, THF; [iv] (a) $n$-BuLi (two equivalents), THF, $-78^{\circ} \mathrm{C}$, (b) trimethylsilyl chloride; [v] mCPBA, $\mathrm{CH}_{2} \mathrm{Cl}_{2}, \mathrm{pH} 7$ phosphate buffer, $0^{\circ} \mathrm{C}, 8 \mathrm{~h}$; [vi] $\mathrm{PhMgBr}, \mathrm{CuI}$, THF, -65 to $-20^{\circ} \mathrm{C}, 1 \mathrm{~h}$; [vii] $\mathrm{SOCl}_{2}$, pyridine, $0^{\circ} \mathrm{C}$ to r.t., $3 \mathrm{~h}$; [viii] DMSO, $\mathrm{H}_{2} \mathrm{O}, 90^{\circ} \mathrm{C}, 3 \mathrm{~h}$. 
Table 2

Substituent effect on complexation diastereoselectivity (Eq. (2))

\begin{tabular}{llll}
\hline Bisindene & $\mathrm{R}^{1}$ & $\mathrm{R}^{2}$ & Ratio $^{\mathrm{a}} \mathbf{8 : 9}$ \\
\hline $\mathbf{4 b}$ & $\mathrm{CH}_{3}$ & $\mathrm{H}$ & $1: 1$ \\
$\mathbf{4 c}$ & $\mathrm{H}$ & $i-\mathrm{Bu}$ & $4: 1$ \\
$\mathbf{4 d}$ & $\mathrm{H}$ & $i-\mathrm{Pr}$ & $2: 1$ \\
$\mathbf{4 e}$ & $\mathrm{H}$ & $\mathrm{Bn}$ & $3.6: 1^{\mathrm{b}}$ \\
$\mathbf{4 f}$ & $\mathrm{H}$ & $\mathrm{SiMe}_{3}$ & $-\mathrm{c}$ \\
$\mathbf{4 g}$ & $\mathrm{H}$ & $\mathrm{Ph}$ & $4.3: 1$ \\
\hline
\end{tabular}

${ }^{\text {a }}$ Determined by ${ }^{1} \mathrm{H}-\mathrm{NMR}$ integration.

${ }^{\mathrm{b}}$ Complexation ratio from Ref. [3].

${ }^{\mathrm{c}}$ No metallocene formation, Ref. [16]

$\mathrm{CH}_{2} \mathrm{Cl}_{2}$. We observed that the epoxidation was effective only when a $\mathrm{pH} 7$ phosphate buffer was used to prevent decomposition of the acid-sensitive benzylic epoxide [12]. Subsequent exposure of the epoxide to $\mathrm{PhMgBr}$ in the presence of catalytic $\mathrm{CuI}$ gave alcohol 7. Elimination of the $3^{\circ}$ alcohol was effected by reaction with thionyl chloride in pyridine. The crude elimination product was then heated in aqueous DMSO [13] to remove the silyl protection group. In this manner, indenyl alcohol $\mathbf{3 g}$ was isolated in 31\% yield from $\mathbf{3 a}$.

With the C(3)-substituted 2-(hydroxymethyl)indenes prepared, we examined their titanium-mediated reductive dehydroxy coupling using the conditions that were optimal for the coupling of $\mathbf{3 a}$. The reactions of the C(3)-substituted substrates afforded 1,2-bis(2-indenyl)ethane derivatives $\mathbf{4}$ with greater regioselectivity than the coupling of unsubstituted indenes (Table 1). The formation of less amounts of the $\alpha$-coupled products 5 is consistent with the expectation that C(3)-substitution might deter reaction at the more hindered center. Substitution of C(3) with phenyl (e.g. 3g) greatly improved the overall yield of the coupling reaction presumably due to greater stabilization of the radical intermediates. However, the regioselectivity of the coupling reaction in this case was somewhat diminished relative to the other $\mathrm{C}(3)$-substituted examples.

\subsection{Ligand complexation}

Preparation of the corresponding ansa-titanocene complexes 8 and $\mathbf{9}$ from bis-indenes $\mathbf{4}$ was accomplished using a literature procedure [3]. Treatment of the corresponding dianions of $\mathbf{4}$ with $\mathrm{TiCl}_{3} \cdot(\text { thf })_{3}$ [14] was followed by oxidative work-up and immediate catalytic hydrogenation of the crude reaction mixture. Mixtures of racemic and meso bis(tetrahydroindenyl) ansa-titanocenes were obtained in varying ratios (Table 2). Previous complexation studies suggested a relationship between the size of the substituent proximal to the ethylene bridge and the diastereomeric (racemic:meso)

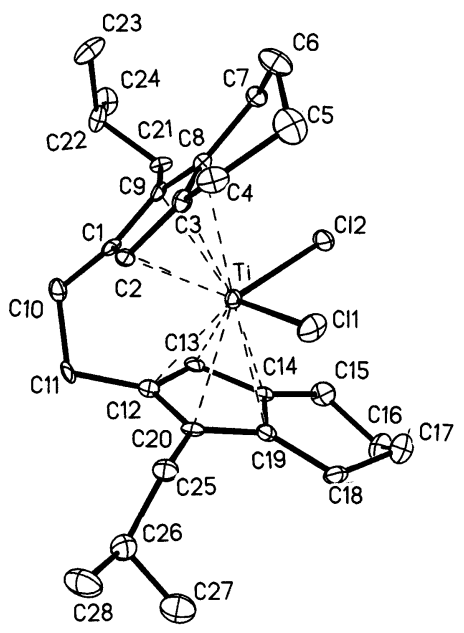

Fig. 1. Molecular structure of compound 8c with 50\% probability ellipsoids depicted and the $\mathrm{H}$ atoms removed for clarity.

ratio $[3,15]$. The observation that a sterically more demanding $\alpha$-substituent slightly favors formation of the racemic isomer is supported by the new examples. Assignments of configuration were based on X-ray crystallographic analyses of recrystallized products obtained from $\mathbf{4 b}-\mathbf{d}$ (Figs. 1-3).

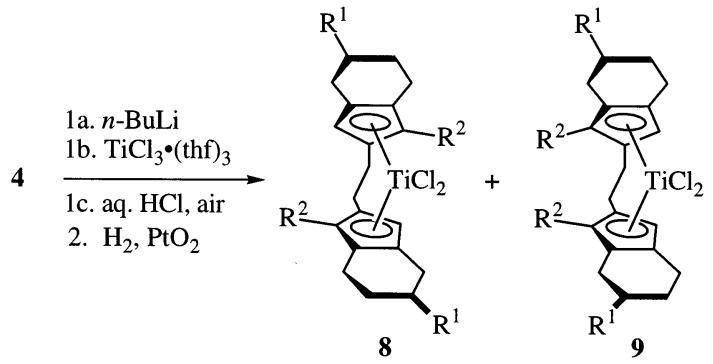

The determination of diastereoselectivity in the complexation of $\mathbf{4} \mathbf{e}$ was made by spectral comparison of the crude hydrogenation mixture to a reference sample of

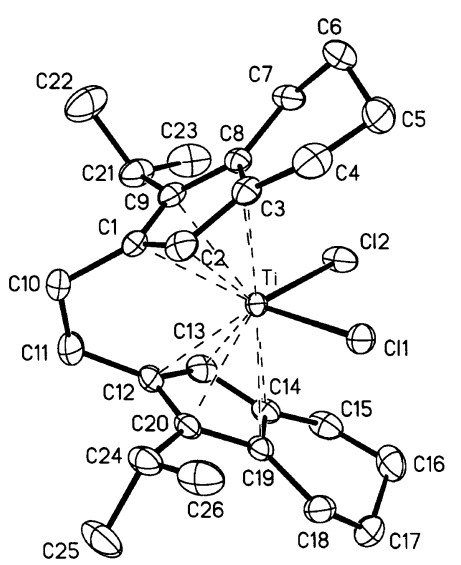

Fig. 2. Molecular structure of compound 8d with $50 \%$ probability ellipsoids depicted and the $\mathrm{H}$ atoms removed for clarity. 


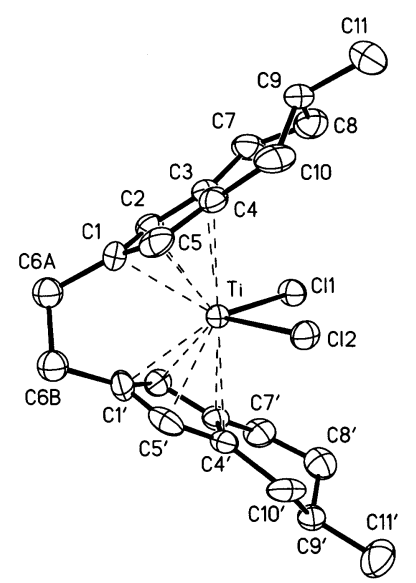

Fig. 3. Molecular structure of compound 9b with $20 \%$ probability ellipsoids depicted and the $\mathrm{H}$ atoms removed for clarity.

the racemic benzyl-substituted (2-tetrahydroindenyl) ansa-titanocene [17].

The largest diastereoselectivity on titanium complexation was observed with phenyl-substituted bis-indene $\mathbf{4 g}$, affording a 4.3:1 preference for the racemic isomer $\mathbf{8 g}$ (Table 2, [18]). Attempts to isolate $\mathbf{8 g}$ by recrystallization from the hydrogenation reaction mixture were unsuccessful. The stereochemical assignment for $\mathbf{8 g}$ is based on the ${ }^{1} \mathrm{H}-\mathrm{NMR}$ spectrum observed for the crude complexation mixture prior to hydrogenation. Collins [15] has previously noted that the meso isomers of $\alpha$-substituted ethylene-bridged ansa-titanocenes exhibit a compact $4 \mathrm{H}$ multiplet corresponding to the ethylene bridge. The racemic isomers exhibit a distinctly separate pair of $2 \mathrm{H}$ multiplets for the ethylene bridge [19]. The major ansa-titanocene that is formed on complexation of $\mathbf{4 g}$ exhibits a pair of $2 \mathrm{H}$ multiplets at $\delta 3.12$ and 2.44 , thus suggesting the assignment of $\mathbf{8 g}$ as the major isomer.

\subsection{X-ray structures of ansa-titanocenes $8 \boldsymbol{c}$-d and $\mathbf{9 b}$}

Crystal data for the three structures are given in Table 3 and selected bond lengths and angles are given in Tables 4-6. All structures were solved by direct methods (SHELXs [20]) and refined by full-matrix least squares based on $F^{2}$ (SHELXL-97 [21]); empirical absorption corrections (XABS2 [22]) were performed. For $\mathbf{9 b}$, there was disorder in the ethylene portion of the ligand. Two positions were used to model this carbon (the other is generated by a mirror plane). A chirality test on 8c was performed and the flack parameter was refined to the value 0.078 (11), indicating the correct sense of chirality as depicted.

Table 3

Crystal data for $\mathbf{8 c}, \mathbf{8 d}$, and $\mathbf{9 b}$

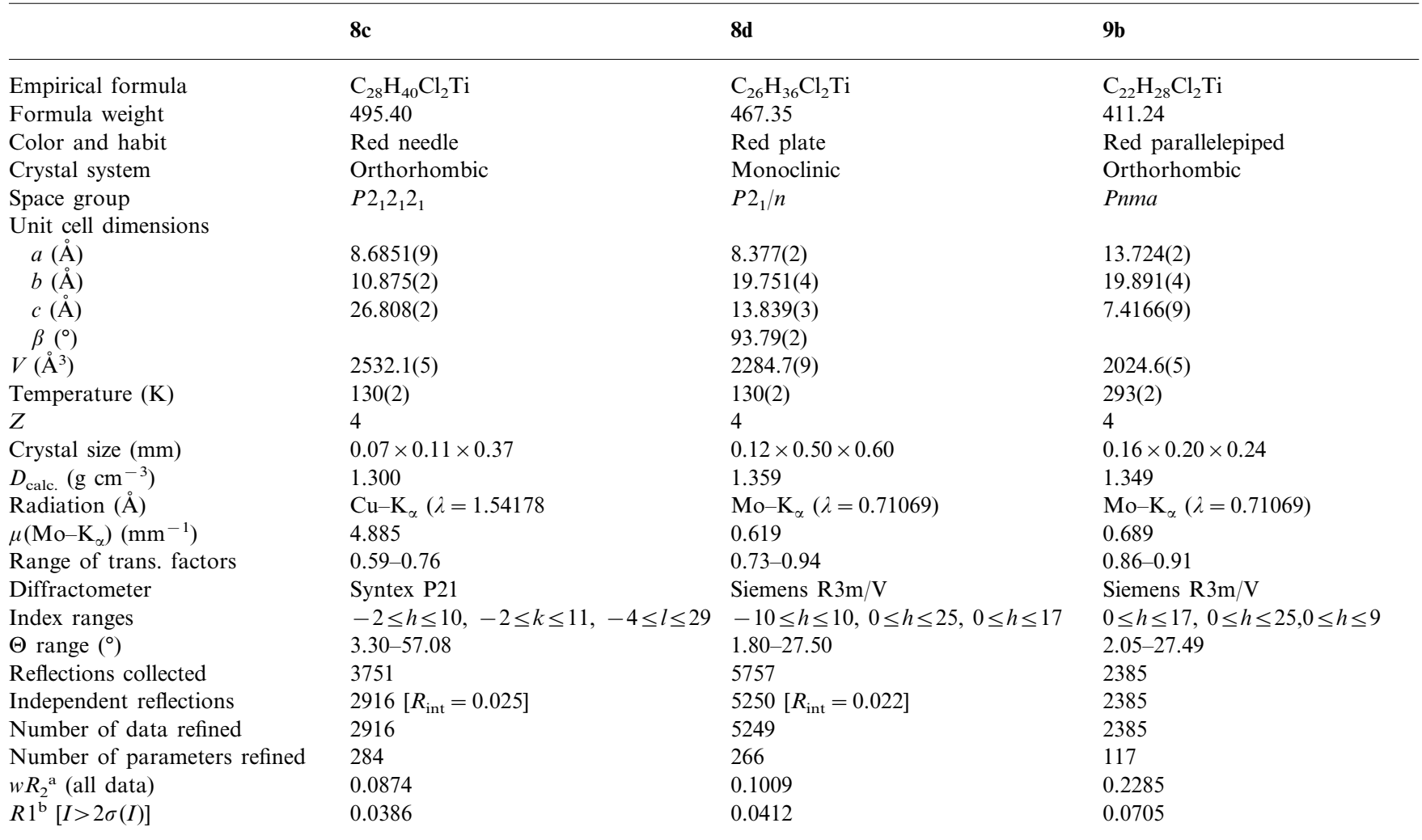

${ }^{\mathrm{a}} w R_{2}=\left[\Sigma\left[w\left(F_{\mathrm{o}}^{2}-F_{\mathrm{c}}^{2}\right)^{2}\right] / \Sigma\left[\left(w F_{\mathrm{o}}^{2}\right)^{2}\right]\right]^{1 / 2} \cdot w=1 /\left[\sigma^{2}\left(F_{\mathrm{o}}^{2}\right)+(\mathrm{aP})^{2}+\mathrm{bP}\right]$ where $\mathrm{P}=\left(F_{\mathrm{o}}^{2}+2 F_{\mathrm{c}}^{2}\right) / 3$.

${ }^{\mathrm{b}} R 1=\Sigma|| F_{\mathrm{o}}|-| F_{\mathrm{c}}|| / \Sigma\left|F_{\mathrm{o}}\right|$. 
Table 4

Selected bond lengths and angles for titanocene $\mathbf{8} \mathbf{c}^{\mathrm{a}}$

\begin{tabular}{llll}
\hline $\begin{array}{l}\text { Bond lengths }(\AA) \\
\text { Ti(1)-Cl(1) }\end{array}$ & 2.0303 & $\mathrm{Ti}(1)-\mathrm{C}(12)$ & \\
$\mathrm{Ti}(1)-\mathrm{Cl}(2)$ & 2.3475 & $\mathrm{Ti}(1)-\mathrm{C}(20)$ & 2.372 \\
$\mathrm{Ti}(1)-\mathrm{C}(1)$ & 2.372 & $\mathrm{Ti}(1)-\mathrm{C}(19)$ & 2.427 \\
$\mathrm{Ti}(1)-\mathrm{C}(2)$ & 2.342 & $\mathrm{C}(12)-\mathrm{C}(20)$ & 2.515 \\
$\mathrm{Ti}(1)-\mathrm{C}(3)$ & 2.487 & $\mathrm{C}(19)-\mathrm{C}(20)$ & 1.410 \\
$\mathrm{C}(1)-\mathrm{C}(2)$ & 1.430 & $\mathrm{C}(18)-\mathrm{C}(19)$ & 1.440 \\
$\mathrm{C}(2)-\mathrm{C}(3)$ & 1.432 & $\mathrm{C}(17)-\mathrm{C}(18)$ & 1.502 \\
$\mathrm{C}(3)-\mathrm{C}(4)$ & 1.494 & $\mathrm{C}(16)-\mathrm{C}(17)$ & 1.519 \\
$\mathrm{C}(4)-\mathrm{C}(5)$ & 1.536 & $\mathrm{CentA}-\mathrm{Ti}$ & 1.527 \\
$\mathrm{C}(5)-\mathrm{C}(6)$ & 1.503 & $\mathrm{CentB}-\mathrm{Ti}$ & 2.115 \\
Bond angles $\left({ }^{\circ}\right)$ & & & 2.111 \\
$\mathrm{Cl}(1)-\mathrm{Ti}(1)-\mathrm{Cl}(2)$ & 96.70 & $\mathrm{C}(6)-\mathrm{C}(5)-\mathrm{C}(4)$ & \\
$\mathrm{C}(9)-\mathrm{C}(1)-\mathrm{C}(2)$ & 107.1 & $\mathrm{C}(8)-\mathrm{C}(9)-\mathrm{C}(21)$ & 112.2 \\
$\mathrm{C}(1)-\mathrm{C}(9)-\mathrm{C}(8)$ & 108.4 & $\mathrm{C}(1)-\mathrm{C}(10)-\mathrm{C}(11)$ & 125.4 \\
$\mathrm{C}(8)-\mathrm{C}(3)-\mathrm{C}(4)$ & 123.9 & $\mathrm{CentA}-\mathrm{Ti}-\mathrm{CentB}$ & 129.9 \\
\end{tabular}

${ }^{a}$ CentA and CentB are the two centroids of the $\eta 5$-coordinated cyclopentadienyl rings.

In summary, we have improved the access to derivatives of 1,2-bis(2-indenyl)ethane. Our approach relies on a titanium-mediated reductive dehydroxy coupling of C(3)-substituted 2-(hydroxymethyl)indenes as the key step. Application of this methodology has provided new chiral, $\alpha$-substituted ansa-titanocenes that may find use in catalytic applications.

\section{Experimental}

Reactions were carried out under argon atmosphere using standard Schlenk techniques. THF and $\mathrm{Et}_{2} \mathrm{O}$ were distilled from Na-benzophenone ketyl immediately prior to use. 1,2-Dimethoxyethane was distilled from $\mathrm{LiAlH}_{4}$. DMF was distilled from $\mathrm{MgSO}_{4}$. All reaction

Table 5

Selected bond lengths and angles for titanocene $\mathbf{8 \mathbf { d } ^ { \mathrm { a } }}$

\begin{tabular}{llll}
\hline $\begin{array}{l}\text { Bond lengths }(\AA) \\
\text { Ti(1)-Cl(1) }\end{array}$ & 2.3307 & $\mathrm{Ti}(1)-\mathrm{C}(12)$ & 2.382 \\
$\mathrm{Ti}(1)-\mathrm{Cl}(2)$ & 2.3426 & $\mathrm{Ti}(1)-\mathrm{C}(20)$ & 2.431 \\
$\mathrm{Ti}(1)-\mathrm{C}(1)$ & 2.385 & $\mathrm{Ti}(1)-\mathrm{C}(19)$ & 2.525 \\
$\mathrm{Ti}(1)-\mathrm{C}(2)$ & 2.342 & $\mathrm{C}(12)-\mathrm{C}(20)$ & 1.428 \\
$\mathrm{Ti}(1)-\mathrm{C}(3)$ & 2.468 & $\mathrm{C}(19)-\mathrm{C}(20)$ & 1.430 \\
$\mathrm{C}(1)-\mathrm{C}(2)$ & 1.401 & $\mathrm{C}(18)-\mathrm{C}(19)$ & 1.505 \\
$\mathrm{C}(2)-\mathrm{C}(3)$ & 1.415 & $\mathrm{C}(17)-\mathrm{C}(18)$ & 1.538 \\
$\mathrm{C}(3)-\mathrm{C}(4)$ & 1.491 & $\mathrm{C}(16)-\mathrm{C}(17)$ & 1.514 \\
$\mathrm{C}(4)-\mathrm{C}(5)$ & 1.509 & $\mathrm{CentA}-\mathrm{Ti}$ & 2.116 \\
$\mathrm{C}(5)-\mathrm{C}(6)$ & 1.515 & $\mathrm{CentB}-\mathrm{Ti}$ & 2.111 \\
Bond angles $\left({ }^{\circ}\right)$ & & & \\
$\mathrm{Cl}(1)-\mathrm{Ti}(1)-\mathrm{Cl}(2)$ & 92.48 & $\mathrm{C}(6)-\mathrm{C}(5)-\mathrm{C}(4)$ & 111.1 \\
$\mathrm{C}(9)-\mathrm{C}(1)-\mathrm{C}(2)$ & 108.3 & $\mathrm{C}(8)-\mathrm{C}(9)-\mathrm{C}(21)$ & 127.9 \\
$\mathrm{C}(1)-\mathrm{C}(9)-\mathrm{C}(8)$ & 107.0 & $\mathrm{C}(1)-\mathrm{C}(10)-\mathrm{C}(11)$ & 111.3 \\
$\mathrm{C}(8)-\mathrm{C}(3)-\mathrm{C}(4)$ & 123.6 & $\mathrm{CentA}-\mathrm{Ti}-\mathrm{CentB}$ & 129.2
\end{tabular}

\footnotetext{
${ }^{a}$ Cent $\mathrm{A}$ and CentB are the two centroids of the $\eta 5$-coordinated cyclopentadienyl rings.
}

Table 6

Selected bond lengths and angles for titanocene $\mathbf{9} \mathbf{b}^{\mathbf{a}}$

\begin{tabular}{lcll}
\hline $\begin{array}{l}\text { Bond lengths }(\AA) \\
\text { Ti(1)-Cl(1) }\end{array}$ & 2.334 & $\mathrm{Ti}(1)-\mathrm{C}\left(1^{\prime}\right)$ & \\
$\mathrm{Ti}(1)-\mathrm{Cl}(2)$ & 2.341 & $\mathrm{Ti}(1)-\mathrm{C}\left(5^{\prime}\right)$ & 2.350 \\
$\mathrm{Ti}(1)-\mathrm{C}(1)$ & 2.350 & $\mathrm{Ti}(1)-\mathrm{C}\left(4^{\prime}\right)$ & 2.361 \\
$\mathrm{Ti}(1)-\mathrm{C}(5)$ & 2.361 & $\mathrm{C}(9)-\mathrm{C}(10)$ & 2.482 \\
$\mathrm{Ti}(1)-\mathrm{C}(4)$ & 2.482 & $\mathrm{C}(8)-\mathrm{C}(9)$ & 1.553 \\
$\mathrm{C}(1)-\mathrm{C}(5)$ & 1.417 & $\mathrm{C}(1)-\mathrm{C}(6 \mathrm{~A})$ & 1.468 \\
$\mathrm{C}(4)-\mathrm{C}(5)$ & 1.402 & $\mathrm{Cent}-\mathrm{Ti}$ & 1.576 \\
$\mathrm{C}(4)-\mathrm{C}(10)$ & 1.550 & $\mathrm{CentB}-\mathrm{Ti}$ & 2.092 \\
Bond angles $\left({ }^{\circ}\right)$ & & & \\
$\mathrm{Cl}(1)-\mathrm{Ti}(1)-\mathrm{Cl}(2)$ & 94.96 & $\mathrm{C}(8)-\mathrm{C}(9)-\mathrm{C}(10)$ & \\
$\mathrm{C}(5)-\mathrm{C}(1)-\mathrm{C}(2)$ & 105.1 & $\mathrm{C}(4)-\mathrm{C}(10)-\mathrm{C}(9)$ & 110.7 \\
$\mathrm{C}(3)-\mathrm{C}(4)-\mathrm{C}(5)$ & 107.0 & $\mathrm{C}(1)-\mathrm{C}(6 \mathrm{~A})-\mathrm{C}(6 \mathrm{~B})$ & 109.4 \\
$\mathrm{C}(4)-\mathrm{C}(5)-\mathrm{C}(1)$ & 109.3 & $\mathrm{CentA}-\mathrm{Ti}-\mathrm{CentB}$ & 12.1 \\
& & & 129.9 \\
\hline
\end{tabular}

${ }^{a}$ Cent $\mathrm{A}$ and $\mathrm{CentB}$ are the two centroids of the $\eta 5$-coordinated cyclopentadienyl rings.

and work-up solvents were removed by rotary evaporation unless otherwise indicated. All column chromatography was performed using silica gel purchased from EM Separations Technology (230-400 mesh). NMR spectra were recorded on a General Electric QE-300 spectrometer. IR spectra were recorded as $\mathrm{CHCl}_{3}$ solutions on a Mattson FTIR 3000 spectrometer. Melting points are uncorrected. Mass spectral analyses were performed by the University of Minnesota Mass Spectrometry Service Laboratory.

\subsection{2-(Hydroxymethyl)-5-methylindene (3b)}

To a stirred solution of methyl phenylsulfonylacetate $(12.5 \mathrm{~g}, 58.4 \mathrm{mmol})$ in DMF $(90 \mathrm{ml})$ at $0^{\circ} \mathrm{C}$, was added in one portion $\mathrm{LiH}(1.40 \mathrm{~g}, 175.2 \mathrm{mmol})$. After stirring for $2 \mathrm{~h}, 3$,4-bis(chloromethyl)toluene (11.7 g, 61.9 $\mathrm{mmol}$ ) was added and the reaction mixture was allowed to warm to room temperature (r.t.). The reaction was recooled to $0^{\circ} \mathrm{C}$ after $48 \mathrm{~h}$, quenched by careful addition of saturated aqueous $\mathrm{NH}_{4} \mathrm{Cl}$, and then diluted with $\mathrm{CH}_{2} \mathrm{Cl}_{2}(200 \mathrm{ml})$ and $\mathrm{H}_{2} \mathrm{O}(150 \mathrm{ml})$. The layers were separated and the aqueous phase was extracted with $\mathrm{CH}_{2} \mathrm{Cl}_{2}$. The combined organic extract was washed with water, saturated brine, and dried $\left(\mathrm{Na}_{2} \mathrm{SO}_{4}\right)$. The solvents were removed by rotary evaporation to afford the crude product. Recrystallization of the residue from methanol gave $15.5 \mathrm{~g}(80 \%)$ of 2-carbomethoxy-2phenylsulfonyl-5-methylindan as a white solid, m.p. $113-114^{\circ} \mathrm{C}$; IR $\left(\mathrm{CHCl}_{3}\right): 3029,1735,1320,1258,1146$ $\mathrm{cm}^{-1} ;{ }^{1} \mathrm{H}-\mathrm{NMR}\left(\mathrm{CDCl}_{3}\right): \delta 2.29(\mathrm{~s}, 3 \mathrm{H}), 3.64(\mathrm{~d}$, $J=17.4 \mathrm{~Hz}, 2 \mathrm{H}), 3.67(\mathrm{~s}, 3 \mathrm{H}), 3.80(\mathrm{~d}, J=16.8 \mathrm{~Hz}$, 2H), $7.02(\mathrm{~m}, 3 \mathrm{H}), 7.54$ (app. t, $J=7.8 \mathrm{~Hz}, 2 \mathrm{H}), 7.65$ (app. t, $J=7.5 \mathrm{~Hz}, 1 \mathrm{H}), 7.85(\mathrm{~d}, J=7.5 \mathrm{~Hz}, 2 \mathrm{H})$; ${ }^{13} \mathrm{C}-\mathrm{NMR}\left(\mathrm{CDCl}_{3}\right): \delta 21.1,38.0,38.2,53.4,79.1,123.8$, $124.7,128.1,128.7,129.7,134.1,135.3,137.0,138.5$, 168.5. HRMS (EI) Calc. for $\mathrm{C}_{18} \mathrm{H}_{18} \mathrm{O}_{4} \mathrm{~S}: 330.0926$. Found: 330.0927. 
To a stirred solution of 2-carbomethoxy-2-phenylsulfonyl-5-methylindan (10.6 g, $32.2 \mathrm{mmol})$ in THF $(110 \mathrm{ml})$ at $-50^{\circ} \mathrm{C}$ was added a solution of $\mathrm{KO} t$ - Bu (90 ml, $1.45 \mathrm{M}$ in THF, $130.5 \mathrm{mmol}$ ). On complete addition, the reaction mixture was stirred for $10 \mathrm{~min}$ and then quenched by addition of saturated aqueous $\mathrm{NH}_{4} \mathrm{Cl}(200 \mathrm{ml})$. The quenched reaction was diluted with EtOAc and the layers were separated. The aqueous layer was extracted with EtOAc. The combined organic extract was washed with $\mathrm{H}_{2} \mathrm{O}$, saturated brine, and dried $\left(\mathrm{Na}_{2} \mathrm{SO}_{4}\right)$. Removal of the solvents afforded the crude product as a 2:1 mixture of methyl and tert-butyl esters. ${ }^{1} \mathrm{H}-\mathrm{NMR}\left(\mathrm{CDCl}_{3}\right): \delta 1.56(\mathrm{~s}, 9 \mathrm{H})$, $2.41(\mathrm{~s}, 6 \mathrm{H}), 3.59$ (br s, 2H), 3.64 (br s, 2H), 3.84 (s, $3 \mathrm{H}), 7.21-7.31(\mathrm{~m}, 8 \mathrm{H})$.

The crude mixture was dissolved in $\mathrm{Et}_{2} \mathrm{O}(160 \mathrm{ml})$ and cooled to $-78^{\circ} \mathrm{C}$. To the solution diisobutylaluminum hydride was added dropwise $(100 \mathrm{ml}$ of a $1.0 \mathrm{M}$ solution in hexane, $100 \mathrm{mmol}$ ). The reaction was allowed to warm to r.t. and stirred for $12 \mathrm{~h}$. The reaction was quenched by slowly pouring the reaction mixture into an Erlenmeyer flask containing a vigorously stirred solution of $3 \mathrm{M} \mathrm{NaOH}(200 \mathrm{ml})$. The layers were separated and the aqueous phase was extracted with additional portions of $\mathrm{Et}_{2} \mathrm{O}$. The combined organic extract was washed with $10 \% \mathrm{HCl}$, saturated brine and dried $\left(\mathrm{MgSO}_{4}\right)$. Removal of the solvents by rotary evaporation afforded $5.03 \mathrm{~g}(97 \%)$ of $\mathbf{3 b}$ as an inseparable mixture of isomers, m.p. $60-61^{\circ} \mathrm{C}$; IR $\left(\mathrm{CHCl}_{3}\right)$ : 3331, 2912, 2859, $1031 \mathrm{~cm}^{-1}$; ${ }^{1} \mathrm{H}-\mathrm{NMR}\left(\mathrm{CDCl}_{3}\right): \delta$ 2.38 (br s, 3H), 3.39 (br s, 2H), 4.57 (br s, 2H), 6.71 (br $\mathrm{s}, 1 \mathrm{H}), 7.15-7.25(\mathrm{~m}, 3 \mathrm{H}) ;{ }^{13} \mathrm{C}-\mathrm{NMR}\left(\mathrm{CDCl}_{3}\right): \delta 21.3$, $38.4,38.7,61.7,120.4,121.5,123.31,124.6,125.3$, $127.0,127.4,134.1,135.9,140.3,141.9,143.7,144.8$, 147.6, 148.9; HRMS (EI) Calc. for $\mathrm{C}_{11} \mathrm{H}_{12} \mathrm{O}: 160.0888$. Found: 160.0881 .

\subsection{2-(tert-Butyldimethylsilyloxymethyl)indene (6)}

To a solution of 2-(hydroxymethyl)indene (10.0 g, $68.4 \mathrm{mmol})$ in $\mathrm{CH}_{2} \mathrm{Cl}_{2}(250 \mathrm{ml})$ at r.t., $\mathrm{Et}_{3} \mathrm{~N}(14.3 \mathrm{ml}$, $103 \mathrm{mmol})$, DMAP $(1.0 \mathrm{~g}, 6.8 \mathrm{mmol})$ and tertbutyldimethylsilyl chloride (11.3 g, $75.2 \mathrm{mmol})$ were added sequentially. After stirring for $2 \mathrm{~h}$, the reaction mixture was cooled to $0^{\circ} \mathrm{C}$ and quenched by addition of saturated aqueous $\mathrm{NH}_{4} \mathrm{Cl}$. The layers were separated and the aqueous phase was extracted with $\mathrm{CH}_{2} \mathrm{Cl}_{2}$. The combined organic extract was washed with water, saturated brine, and dried $\left(\mathrm{Na}_{2} \mathrm{SO}_{4}\right)$. The solvents were removed and the residue was passed through a short column of silica, eluting with 3:1 hexane:ethyl acetate, to afford $16.9 \mathrm{~g}(95 \%)$ of $\mathbf{6}$ as a yellow solid; m.p. $35-36^{\circ} \mathrm{C}$; IR $\left(\mathrm{CHCl}_{3}\right): 3059,2955,1471,1097,836$ $\mathrm{cm}^{-1} ;{ }^{1} \mathrm{H}-\mathrm{NMR}\left(\mathrm{CDCl}_{3}\right): \delta 0.14(\mathrm{~s}, 6 \mathrm{H}), 0.98(\mathrm{~s}, 9 \mathrm{H})$, $3.37(\mathrm{~s}, 2 \mathrm{H}), 4.61(\mathrm{~s}, 2 \mathrm{H}), 6.71(\mathrm{~s}, 1 \mathrm{H}), 7.15-7.43(\mathrm{~m}$, $4 \mathrm{H}) ;{ }^{13} \mathrm{C}-\mathrm{NMR}\left(\mathrm{CDCl}_{3}\right): \delta-5.3,18.4,25.9,38.7,62.2$,
120.6, 123.6, 124.1, 126.2, 126.6, 143.2, 144.9, 149.3; HRMS (EI) Calc. for $\mathrm{C}_{16} \mathrm{H}_{24} \mathrm{OSi}$ : 260.1596. Found: 260.1597.

\subsection{2-(tert-Butyldimethylsilyloxymethyl)-1-phenyl- indan-2-ol (7)}

To a solution of 2-(tert-butyldimethylsilyloxymethyl)indene $(107 \mathrm{mg}, 0.411 \mathrm{mmol})$ in $\mathrm{CH}_{2} \mathrm{Cl}_{2}(6.9$ $\mathrm{ml})$, a phosphate buffer $(6.9 \mathrm{ml}, \mathrm{pH} 7,0.05 \mathrm{M}$ in both $\mathrm{KH}_{2} \mathrm{PO}_{4}$ and $\mathrm{Na}_{2} \mathrm{HPO}_{4}$ ) was added. To the biphasic mixture at $0^{\circ} \mathrm{C}$ was added 'acid free' $m$-CPBA [23] (78 $\mathrm{mg}, 0.452 \mathrm{mmol}$ ) in one portion. After $8 \mathrm{~h}$ the reaction mixture was poured into a 1:1 mixture of saturated aqueous $\mathrm{NaHCO}_{3}(20 \mathrm{ml})$ and saturated aqueous $\mathrm{Na}_{2} \mathrm{~S}_{2} \mathrm{O}_{3}(20 \mathrm{ml})$ and extracted with $\mathrm{CH}_{2} \mathrm{Cl}_{2}$ three times. The combined organic extract was dried over $\mathrm{Na}_{2} \mathrm{SO}_{4}$, and the solvents were removed under reduced pressure to afford the crude epoxide. ${ }^{1} \mathrm{H}-\mathrm{NMR}$ $\left(\mathrm{CDCl}_{3}\right): \delta 0.11(\mathrm{~s}, 3 \mathrm{H}), 0.12(\mathrm{~s}, 3 \mathrm{H}), 0.93(\mathrm{~s}, 9 \mathrm{H}), 3.08$ $(\mathrm{d}, J=17.7 \mathrm{~Hz}, 1 \mathrm{H}), 3.16(\mathrm{~d}, J=17.9 \mathrm{~Hz}, 1 \mathrm{H}), 4.01$ (d, $J=11.7 \mathrm{~Hz}, 1 \mathrm{H}), 4.11(\mathrm{~d}, J=11.7 \mathrm{~Hz}, 1 \mathrm{H}), 4.17(\mathrm{~d}$, $J=0.74 \mathrm{~Hz}, 1 \mathrm{H}), 7.15-7.26(\mathrm{~m}, 3 \mathrm{H}), 7.46(\mathrm{~d}, J=7.2$ $\mathrm{Hz}, 1 \mathrm{H})$.

To a suspension of $\mathrm{CuI}$ in $\mathrm{THF}(3 \mathrm{ml})$ at $-40^{\circ} \mathrm{C}$, $\mathrm{PhMgBr}\left(411 \mathrm{ml}, 3.0 \mathrm{M}\right.$ solution in $\left.\mathrm{Et}_{2} \mathrm{O}, 1.23 \mathrm{mmol}\right)$ was added. After stirring for $15 \mathrm{~min}$ the reaction was cooled to $-65^{\circ} \mathrm{C}$ and a solution of the crude epoxide in THF $(1 \mathrm{ml})$ was added dropwise via cannula. The reaction was warmed to $-20^{\circ} \mathrm{C}$ over $50 \mathrm{~min}$ in which time the reaction was quenched with a saturated aqueous solution of $\mathrm{NH}_{4} \mathrm{Cl}$ and diluted with $\mathrm{Et}_{2} \mathrm{O}$. The organic layer was washed with water, saturated brine, and dried over $\mathrm{Na}_{2} \mathrm{SO}_{4}$. The solvents were removed and the residue was purified by chromatography, eluting with $2 \%$ ethyl acetate/hexane on $\mathrm{SiO}_{2}$, to afford $119 \mathrm{mg}$ $(82 \%)$ of alcohol 7 as a colorless oil. IR (neat) 3563, 3466, 3064, 3027, 1602, 1558, 1494, 1089, $1079 \mathrm{~cm}^{-1}$; ${ }^{1} \mathrm{H}-\mathrm{NMR}\left(\mathrm{CDCl}_{3}\right): \delta 0.01(\mathrm{~s}, 3 \mathrm{H}), 0.04(\mathrm{~s}, 3 \mathrm{H}), 0.97$ (s, $9 \mathrm{H}), 3.07(\mathrm{~d}, J=16.2 \mathrm{~Hz}, 1 \mathrm{H}), 3.24,(\mathrm{~s}, 1 \mathrm{H}), 3.26(\mathrm{~d}$, $J=16.4 \mathrm{~Hz}, 1 \mathrm{H}), 3.32(\mathrm{~d}, J=9.7 \mathrm{~Hz}, 1 \mathrm{H}), 3.40(\mathrm{~d}$, $J=9.7 \mathrm{~Hz}, 1 \mathrm{H}), 4.54(\mathrm{~s}, 1 \mathrm{H}), 7.13-7.39(\mathrm{~m}, 9 \mathrm{H})$; ${ }^{13} \mathrm{C}-\mathrm{NMR}\left(\mathrm{CDCl}_{3}\right): \delta-5.7,-5.6,18.1,25.8,42.8$, 61.2, 66.9, 84.2, 124.7, 125.5, 126.6, 126.8, 127.0, 128.1, 129.0, 139.8, 140.9, 144.5; HRMS (EI) Calc. for $\mathrm{C}_{22} \mathrm{H}_{30} \mathrm{O}_{2} \mathrm{Si}$ : 354.2015. Found: 354.2016.

\subsection{2-(Hydroxymethyl)-3-(2-methylpropyl)indene (3c)}

To a solution of silyl ether $6(4.0 \mathrm{~g}, 15.4 \mathrm{mmol})$ in THF $(75 \mathrm{ml})$ at $-78^{\circ} \mathrm{C}, n$-BuLi $(5.0 \mathrm{ml}$ of a $2.5 \mathrm{M}$ solution in hexanes, $17.5 \mathrm{mmol}$ ) was added dropwise. After stirring for $1 \mathrm{~h}, 1$-bromo-2-methylpropane (2.5 $\mathrm{ml}, 23.1 \mathrm{mmol})$ and tetrabutylammonium iodide (1.14 $\mathrm{g}, 3.08 \mathrm{mmol}$ ) were added and the reaction mixture was 
warmed gradually to r.t. and followed by stirring at $55^{\circ} \mathrm{C}$ for $12 \mathrm{~h}$. The solution was then cooled to $0^{\circ} \mathrm{C}$ and quenched by addition of saturated aqueous $\mathrm{NH}_{4} \mathrm{Cl}$. The layers were separated and the aqueous phase was extracted with $\mathrm{Et}_{2} \mathrm{O}$. The combined organic extract was washed with water, saturated brine, and dried $\left(\mathrm{Na}_{2} \mathrm{SO}_{4}\right)$. The solvents were removed and the residue was dissolved in THF (100 ml) and then treated at r.t. with tert-butylammonium fluoride $(46.2 \mathrm{ml}$ of a $1 \mathrm{M}$ solution in THF, $46.2 \mathrm{mmol}$ ). After stirring for $30 \mathrm{~min}$, the reaction mixture was quenched by addition of saturated aqueous $\mathrm{NH}_{4} \mathrm{Cl}$. The layers were separated and the aqueous phase was extracted with $\mathrm{Et}_{2} \mathrm{O}$. The combined organic extract was washed with water, saturated brine, and dried $\left(\mathrm{Na}_{2} \mathrm{SO}_{4}\right)$. The solvents were removed and the crude product was purified by chromatography, eluting with 5:1 hexane:ethyl acetate, to afford $1.49 \mathrm{~g}$ $(48 \%)$ of alcohol 3c as a yellow oil. IR $\left(\mathrm{CHCl}_{3}\right): 3363$, 3019, 2945, $1460 \mathrm{~cm}^{-1} ;{ }^{1} \mathrm{H}-\mathrm{NMR}\left(\mathrm{CDCl}_{3}\right): \delta 0.93(\mathrm{~d}$, $J=6 \mathrm{~Hz}, 6 \mathrm{H}), 1.90-1.97(\mathrm{~m}, 1 \mathrm{H}), 2.42(\mathrm{~d}, J=6 \mathrm{~Hz}$, 2H), 3.46 (s, 2H), 4.51 (s, 2H), 7.14-7.32 (m, 3H), 7.41 $(\mathrm{d}, J=7.2 \mathrm{~Hz}, 1 \mathrm{H}) ;{ }^{13} \mathrm{C}-\mathrm{NMR}\left(\mathrm{CDCl}_{3}\right): \delta$ 22.8, 28.0, 34.6, 38.9, 59.0, 119.6, 123.6, 124.6, 126.0, 139.2, 141.1, 143.0, 146.0; HRMS (EI) Calc. for $\mathrm{C}_{14} \mathrm{H}_{18} \mathrm{O}$ : 202.1358. Found: 202.1347.

\subsection{2-(Hydroxymethyl)-3-(1-methylethyl)indene (3d)}

The preparation of 2-(hydroxymethyl)-3-(1-methylethyl)indene (3d) was accomplished according to the procedure described for the preparation 3c: $2.0 \mathrm{~g}$ of $\mathbf{6}$ ( $7.68 \mathrm{mmol})$, and $0.96 \mathrm{ml}$ of 2-iodopropane $(9.6 \mathrm{mmol})$ were reacted to afford 3d as a yellow oil $(0.38 \mathrm{~g}, 26 \%)$. IR $\left(\mathrm{CHCl}_{3}\right): 3370,2930,1461 \mathrm{~cm}^{-1} ;{ }^{1} \mathrm{H}-\mathrm{NMR}$ $\left(\mathrm{CDCl}_{3}\right): \delta 1.22(\mathrm{~d}, J=6 \mathrm{~Hz}, 6 \mathrm{H}), 3.01-3.10(\mathrm{~m}, 1 \mathrm{H})$, $3.26(\mathrm{~s}, 2 \mathrm{H}), 4.38(\mathrm{~s}, 2 \mathrm{H}), 7.03(\mathrm{t}, J=7.2 \mathrm{~Hz}, 1 \mathrm{H}), 7.14$ $(\mathrm{t}, J=6.6 \mathrm{~Hz}, 1 \mathrm{H}), 7.27(\mathrm{~d}, J=7.2 \mathrm{~Hz}, 1 \mathrm{H}), 7.38(\mathrm{~d}$, $J=7.5 \mathrm{~Hz}, 1 \mathrm{H}) ;{ }^{13} \mathrm{C}-\mathrm{NMR}\left(\mathrm{CDCl}_{3}\right): \delta 21.3,26.6,39.2$, $58.6,120.9,123.7,124.2,125.6,138.9,143.5,144.4$, 145.0; HRMS (EI) Calc. for $\mathrm{C}_{13} \mathrm{H}_{16} \mathrm{O}: 188.1201$. Found: 188.1197.

\subsection{3-Benzyl-2-(hydroxymethyl)indene (3e)}

The preparation of 3-benzyl-2-(hydroxymethyl)indene (3e) was accomplished according to the procedure described for the preparation of 3c: $0.86 \mathrm{~g}$ of $\mathbf{6}$ (3.31 $\mathrm{mmol}$ ), and $0.59 \mathrm{ml}$ of benzylbromide $(4.97 \mathrm{mmol})$ were reacted to afford $3 \mathbf{e}$ as a yellow solid $(0.58 \mathrm{~g}, 74 \%)$. m.p. $87-88^{\circ} \mathrm{C}$; IR $\left(\mathrm{CHCl}_{3}\right)$ : 3339, 3061, 2915, 1601, $1494 \mathrm{~cm}^{-1} ;{ }^{1} \mathrm{H}-\mathrm{NMR}\left(\mathrm{CDCl}_{3}\right): \delta 3.57(\mathrm{~s}, 2 \mathrm{H}), 3.98(\mathrm{~s}$, 2H), 4.63 (s, 2H), 7.17-7.44 (m, 8H), 7.45 (app. d, $J=6.9 \mathrm{~Hz}, 1 \mathrm{H}) ;{ }^{13} \mathrm{C}-\mathrm{NMR}\left(\mathrm{CDCl}_{3}\right): \delta 31.1,39.1,58.7$, $119.8,123.5,124.7,126.0,126.1,128.2,128.4,137.8$, 139.3, 141.9, 142.9, 145.5; HRMS (EI) Calc. for $\mathrm{C}_{17} \mathrm{H}_{16} \mathrm{O}: 236.1201$. Found: 236.1209 .

\subsection{1-Trimethylsilyl-2-(hydroxymethyl)indene (3f)}

To a solution of 2-(hydroxymethyl)indene $(0.25 \mathrm{~g}$, $1.71 \mathrm{mmol})$ in THF $(5 \mathrm{ml})$ at $0^{\circ} \mathrm{C}, n-\mathrm{BuLi}(1.40 \mathrm{ml}$ of a $2.5 \mathrm{M}$ solution in hexanes, $3.51 \mathrm{mmol}$ ) was added dropwise. After stirring at $0^{\circ} \mathrm{C}$ for $0.5 \mathrm{~h}$ and at r.t. for $0.5 \mathrm{~h}$, the reaction mixture was recooled to $0^{\circ} \mathrm{C}$ and chlorotrimethylsilane $(0.50 \mathrm{ml}, 3.68 \mathrm{mmol})$ was added. The reaction mixture was gradually warmed to r.t. and stirred for $12 \mathrm{~h}$. The solution was then cooled to $0^{\circ} \mathrm{C}$ and quenched by addition of saturated aqueous $\mathrm{NaHCO}_{3}$. The layers were separated and the aqueous phase was extracted with EtOAc. The combined organic extract was washed with water, saturated brine, and dried $\left(\mathrm{MgSO}_{4}\right)$. The solvents were removed and the crude product was purified by chromatography, eluting with 5:1 hexane:ethyl acetate, to afford $0.36 \mathrm{~g}(97 \%)$ of alcohol $3 f$ as a yellow oil. IR $\left(\mathrm{CHCl}_{3}\right): 3335,2952$, 1457, $838 \mathrm{~cm}^{-1}$; ${ }^{1} \mathrm{H}-\mathrm{NMR}\left(\mathrm{CDCl}_{3}\right): \delta-0.07$ (s, 9H), 3.50 (s, 1H), 4.48 (dd, $J=15.3,1.0 \mathrm{~Hz}, 1 \mathrm{H}), 4.58$ (dd, $J=15.3,1.0 \mathrm{~Hz}, 1 \mathrm{H}), 6.74(\mathrm{~d}, J=1.0 \mathrm{~Hz}, 1 \mathrm{H})$, 7.06-7.17 (m, $2 \mathrm{H}$ ), 7.30-7.33 (app. d, $J=8.7 \mathrm{~Hz}, 2$ $\mathrm{H}) ;{ }^{13} \mathrm{C}-\mathrm{NMR}\left(\mathrm{CDCl}_{3}\right): \delta-2.1,46.3,62.2,120.8$, 123.1, 123.2, 125.1, 125.7, 144.0, 145.6, 151.0; HRMS (EI) Calc. for $\mathrm{C}_{13} \mathrm{H}_{18} \mathrm{OSi}$ : 218.1127. Found: 218.1127.

\subsection{2-(Hydroxymethyl)-3-phenylindene (3g)}

To a solution of 2-(tert-butyldimethylsilyloxymethyl)-1-phenylindan-2-ol $(1.0 \mathrm{~g}, 2.8 \mathrm{mmol})$ in pyridine (28 $\mathrm{ml})$ at $0^{\circ} \mathrm{C}, \mathrm{SOCl}_{2}(327 \mathrm{ml}, 4.48 \mathrm{mmol})$ was added dropwise via syringe. The reaction was stirred $2 \mathrm{~h}$ at $0^{\circ} \mathrm{C}$ and then $30 \mathrm{~min}$ at r.t. The reaction was quenched by addition of saturated aqueous $\mathrm{NH}_{4} \mathrm{Cl}$ and then diluted with $\mathrm{Et}_{2} \mathrm{O}$. The $\mathrm{Et}_{2} \mathrm{O}$ layer was washed three times with saturated aqueous $\mathrm{CuSO}_{4}$ and followed by washing with water. The combined aqueous layers were extracted with $\mathrm{Et}_{2} \mathrm{O}$. The combined $\mathrm{Et}_{2} \mathrm{O}$ layers were washed with saturated brine and dried over $\mathrm{Na}_{2} \mathrm{SO}_{4}$. Removal of the solvents under reduced pressure afforded the crude silyloxy indene [ ${ }^{1} \mathrm{H}-\mathrm{NMR}\left(\mathrm{CDCl}_{3}\right): \delta$ $0.07(\mathrm{~s}, 6 \mathrm{H}), 0.94(\mathrm{~s}, 9 \mathrm{H}), 3.68$ (s, 2H), $4.64(\mathrm{~s}, 2 \mathrm{H})$, $7.13-7.55(\mathrm{~m}, 9 \mathrm{H})$ ], which was dissolved in a $5: 1 \mathrm{mix}-$ ture of DMSO:water $(16.8 \mathrm{ml})$ and heated to $90^{\circ} \mathrm{C}$. After $3 \mathrm{~h}$ the reaction was poured into water and extracted with $\mathrm{Et}_{2} \mathrm{O}$. The combined organic layers were washed with water, saturated brine, and dried $\left(\mathrm{Na}_{2} \mathrm{SO}_{4}\right)$. The solvents were removed and the residue was purified by chromatography, eluting with $20 \%$ ethyl acetate/hexane on aluminum oxide (activated, basic, Brockmann 1), to afford $243 \mathrm{mg}(39 \%)$ of alcohol 3g as a beige solid, m.p. $100-101^{\circ} \mathrm{C}$; IR (powder): 3362 , $3280, \quad 2952, \quad 1492, \quad 1460,1444 \mathrm{~cm}-1 ;{ }^{1} \mathrm{H}-\mathrm{NMR}$ $\left(\mathrm{CDCl}_{3}\right): \delta 1.46(\mathrm{t}, J=5.72 \mathrm{~Hz}, 1 \mathrm{H}), 3.68(\mathrm{~s}, 2 \mathrm{H}), 4.58$ $(\mathrm{d}, J=6.35 \mathrm{~Hz}, 2 \mathrm{H}), 7.20-7.53(\mathrm{~m}, 9 \mathrm{H}) ;{ }^{13} \mathrm{C}-\mathrm{NMR}$ $\left(\mathrm{CDCl}_{3}\right): \delta 39.5,59.5,120.5,123.8,125.1,126.3,127.6$, 
128.5, 129.1, 134.7, 141.3, 142.4, 143.0, 145.6; HRMS (EI) Calc. for $\mathrm{C}_{16} \mathrm{H}_{14} \mathrm{O}$ : 222.1045. Found: 222.1045.

\subsection{1,2-Bis(2-indenyl)ethane (4a)}

To a stirred solution of $\mathrm{TiCl}_{3}(1.6 \mathrm{~g}, 10.3 \mathrm{mmol})$ in 1,2-dimethoxyethane at $0^{\circ} \mathrm{C}, \mathrm{LiAlH}_{4}(0.13 \mathrm{~g}, 3.42$ $\mathrm{mmol})$ was added in one portion. After stirring for 15 min, a solution of 3a $(0.5 \mathrm{~g}, 3.42 \mathrm{mmol})$ in 1,2dimethoxyethane was cannulated into the resultant black reaction mixture. After gradual warming to r.t., the reaction mixture was refluxed for $16 \mathrm{~h}$. The solution was then cooled to $0^{\circ} \mathrm{C}$ and quenched by addition of 1 $\mathrm{M} \mathrm{HCl}$. The layers were separated and the aqueous phase was extracted with EtOAc. The combined organic extract was washed with water, saturated brine, and dried $\left(\mathrm{Na}_{2} \mathrm{SO}_{4}\right)$. The solvents were removed and the crude product was purified by chromatography, eluting with hexane to afford $0.079 \mathrm{~g}(18 \%)$ of $\mathbf{4 a}$ and $0.078 \mathrm{~g}(18 \%)$ of 5a. [Note: purification problems were encountered when polar solvents such as $\mathrm{CH}_{2} \mathrm{Cl}_{2}$ were used during chromatography. For best results, a solution of the crude product is added to a small amount of silica and the suspension is evaporated to dryness. The dry impregnated silica is then added to the top of a silica gel chromatography column and eluted with hexane].

Compound 5a: m.p. $55-56^{\circ} \mathrm{C}$; IR $\left(\mathrm{CHCl}_{3}\right)$ : 3068, 1653, 1609, $1478 \mathrm{~cm}^{-1} ;{ }^{1} \mathrm{H}-\mathrm{NMR}\left(\mathrm{CDCl}_{3}\right): \delta 2.84$ (app. $\mathrm{d}, J=6.6 \mathrm{~Hz}, 2 \mathrm{H}), 3.17$ (br s, $2 \mathrm{H}), 3.57$ (br s, 2H), 3.95 $(\mathrm{m}, 1 \mathrm{H}), 5.00(\mathrm{~d}, J=1.8 \mathrm{~Hz}, 1 \mathrm{H}), 5.05(\mathrm{~d}, J=1.8 \mathrm{~Hz}$, $1 \mathrm{H}), \quad 6.41(\mathrm{~s}, \quad 1 \mathrm{H}), \quad 6.99-7.28(\mathrm{~m}, \quad 8 \mathrm{H}) ;{ }^{13} \mathrm{C}-\mathrm{NMR}$ $\left(\mathrm{CDCl}_{3}\right): \delta 37.9,38.6,41.7,49.1,108.2,120.1,123.4$, $123.7,124.3,124.4,126.2,126.4,126.8,128.7,141.4$, 143.3, 145.4, 145.6, 147.7, 152.3; HRMS (EI) Calc. for $\mathrm{C}_{20} \mathrm{H}_{18}$ : 258.1408. Found: 258.1402.

\subsection{1,2-Bis[(5-methyl)-2-indenyl)]ethane (4b)}

The preparation of $\mathbf{4 b}$ was accomplished according to the procedure described for preparation of $4 \mathrm{a}: 1.0 \mathrm{~g}$ of 3b $(6.24 \mathrm{mmol})$ was treated with $\mathrm{TiCl}_{3}$ to afford $\mathbf{4 b}$ as a mixture with $\mathbf{5 b}$.

Compound 4b: white solid (0.16 g, 18\%); m.p. 130$131^{\circ} \mathrm{C}$; IR $\left(\mathrm{CHCl}_{3}\right): 2923,2900,1603,878 \mathrm{~cm}^{-1} ;{ }^{1} \mathrm{H}-$ NMR $\left(\mathrm{CDCl}_{3}\right): \delta 2.48(\mathrm{~s}, 6 \mathrm{H}), 2.96(\mathrm{~s}, 4 \mathrm{H}), 3.39(\mathrm{~s}$, $4 \mathrm{H}), 6.61 \quad(\mathrm{~s}, 2 \mathrm{H}), \quad 6.96-7.34(\mathrm{~m}, 6 \mathrm{H}) ;{ }^{13} \mathrm{C}-\mathrm{NMR}$ $\left(\mathrm{CDCl}_{3}\right): \delta 21.4,30.7,40.7,40.9,104.9,119.6,120.8$, 123.1, 124.4, 126.3, 126.5, 126.9; HRMS (EI) Calc. for $\mathrm{C}_{22} \mathrm{H}_{22}$ : 286.1721. Found: 286.1726 .

Compound 5b: yellow oil $(0.17 \mathrm{~g}, 18 \%)$; IR $\left(\mathrm{CHCl}_{3}\right)$ : 3007, 2918, 1616, $805 \mathrm{~cm}^{-1}$; ${ }^{1} \mathrm{H}-\mathrm{NMR}\left(\mathrm{CDCl}_{3}\right): \delta 2.20$ (br s, 3H), 2.25 (br s, 3H), 2.78 (br s, 2H), 3.08 (br s, $2 \mathrm{H}), 3.50$ (br s, 2H), 3.86 (br s, 1H), 4.94 (br s, 1H), 5.01 (br s, 1H), 6.34 (br s, 1H), 6.84-7.19 (m, 6H); ${ }^{13} \mathrm{C}-\mathrm{NMR}\left(\mathrm{CDCl}_{3}\right): \delta 21.5,37.6,37.8,38.0,38.1,38.3$,
$38.5,40.9,41.0,41.1,41.2,48.5,48.8,48.9,107.6,107.7$, $107.9,119.4,119.5,119.6,120.4,120.4,120.5,120.7$, $122.7,122.9,123.0,123.2,123.3,123.4,123.5,123.6$, $123.7,123.9,124.0,124.2,124.3,124.5,124.7,124.9$, 125.0, 125.2,125.3, 125.4; HRMS (EI) Calc. for $\mathrm{C}_{22} \mathrm{H}_{22}$ : 286.1721. Found: 286.1730.

\subsection{1,2-Bis[(3-(2-methylpropyl)-2-indenyl)]ethane (4c)}

The preparation of $\mathbf{4} \mathbf{c}$ was accomplished according to the procedure described for the preparation of $\mathbf{4 a}: 1.20$ g of $3 \mathbf{c}(5.93 \mathrm{mmol})$ was treated with $\mathrm{TiCl}_{3}$ to afford a mixture of $\mathbf{4 c}$ and $\mathbf{5 c}$.

Compound 4c: white solid $(0.33$ g, 30\%); m.p. $70-$ $73^{\circ} \mathrm{C}$; IR $\left(\mathrm{CHCl}_{3}\right): 2951,1364,787 \mathrm{~cm}^{-1} ;{ }^{1} \mathrm{H}-\mathrm{NMR}$ $\left(\mathrm{CDCl}_{3}\right): \delta 0.95(\mathrm{~d}, J=9 \mathrm{~Hz}, 12 \mathrm{H}), 1.95-2.02(\mathrm{~m}, 2 \mathrm{H})$, $2.41(\mathrm{~d}, J=9 \mathrm{~Hz}, 4 \mathrm{H}), 2.69(\mathrm{~s}, 4 \mathrm{H}), 3.37$ (s, 4H), $7.10-7.16(\mathrm{~m}, 6 \mathrm{H}), 7.40$ (app. d, $J=7.2 \mathrm{~Hz}, 2 \mathrm{H}$ ); ${ }^{13} \mathrm{C}-\mathrm{NMR}\left(\mathrm{CDCl}_{3}\right): \delta 23.0,23.1,28.1,29.2,34.7,40.1$, $118.8,123.2,123.6,126.0,136.8,142.5,142.8,146.8$; HRMS (EI) Calc. for $\mathrm{C}_{28} \mathrm{H}_{34}: 370.2660$. Found: 370.2660 .

Compound 5c: yellow solid (0.058 g, 5\%); m.p. 112 $113^{\circ} \mathrm{C}$; IR $\left(\mathrm{CHCl}_{3}\right): 3042,1654,1465,882 \mathrm{~cm}^{-1} ;{ }^{1} \mathrm{H}-$ NMR $\left(\mathrm{CDCl}_{3}\right): \delta 0.49(\mathrm{~d}, J=6.6 \mathrm{~Hz}, 3 \mathrm{H}), 0.77(\mathrm{~d}$, $J=6.6 \mathrm{~Hz}, 3 \mathrm{H}), 0.85(\mathrm{~d}, J=6.6 \mathrm{~Hz}, 3 \mathrm{H}), 0.91(\mathrm{~d}$, $J=6.6 \mathrm{~Hz}, 3 \mathrm{H}), 1.42(\mathrm{~m}, 1 \mathrm{H}), 1.86(\mathrm{~m}, 3 \mathrm{H}), 2.27(\mathrm{~d}$, $J=7.2 \mathrm{~Hz}, 2 \mathrm{H}), 2.47(\mathrm{~d}, J=22.8 \mathrm{~Hz}, 1 \mathrm{H}), 2.70(\mathrm{~d}$, $J=22.8 \mathrm{~Hz}, 1 \mathrm{H}), 2.82(\mathrm{~d}, J=14.4 \mathrm{~Hz}, 1 \mathrm{H}), 2.95(\mathrm{~d}$, $J=14.4 \mathrm{~Hz}, 1 \mathrm{H}), 3.46(\mathrm{~d}, J=21.3 \mathrm{~Hz}, 1 \mathrm{H}), 3.60(\mathrm{~d}$, $J=21.3 \mathrm{~Hz}, 1 \mathrm{H}), 5.08(\mathrm{~m}, 1 \mathrm{H}), 5.18(\mathrm{~m}, 1 \mathrm{H}), 6.95-7.19$ $(\mathrm{m}, 8 \mathrm{H}) ;{ }^{13} \mathrm{C}-\mathrm{NMR}\left(\mathrm{CDCl}_{3}\right): \delta 22.8,23.2,24.4,25.1$, 25.3, 28.0, 34.9, 39.2, 41.7, 43.8, 52.2, 56.3, 107.8, 118.8, $122.8,123.4,124.2,124.3,125.5,126.4,126.9,138.8$, 140.4, 141.1, 143.3, 146.3, 148.2, 154.9; HRMS (EI) Calc. for $\mathrm{C}_{28} \mathrm{H}_{34}: 370.2660$. Found: 370.2661 .

\subsection{1,2-Bis[(3-(1-methylethyl)-2-indenyl)]ethane (4d)}

The preparation of $\mathbf{4 d}$ was accomplished according to the procedure described for the preparation of $4 \mathbf{a}: 0.16$ $\mathrm{g}$ of $\mathbf{3 d}(0.82 \mathrm{mmol})$ was treated with $\mathrm{TiCl}_{3}$ to afford $\mathbf{4 d}$ as a mixture with $\mathbf{5 d}$.

Compound 4d: white solid (0.041 g, 29\%); m.p. 94$95^{\circ} \mathrm{C}$; IR $\left(\mathrm{CHCl}_{3}\right): 2962,1559,1457,766 \mathrm{~cm}^{-1} ;{ }^{1} \mathrm{H}-$ NMR $\left(\mathrm{CDCl}_{3}\right): \delta 1.31(\mathrm{~d}, J=6.9 \mathrm{~Hz}, 12 \mathrm{H}), 2.68(\mathrm{~s}$, $4 \mathrm{H}), 3.13(\mathrm{~m}, 2 \mathrm{H}), 3.30(\mathrm{~s}, 4 \mathrm{H}), 7.10(\mathrm{~m}, 2 \mathrm{H}), 7.22(\mathrm{~m}$, 2H), 7.38 (app. d, $J=7.5 \mathrm{~Hz}, 2 \mathrm{H}$ ), 7.45 (app. d, $J=7.5$ $\mathrm{Hz}, 2 \mathrm{H}) ;{ }^{13} \mathrm{C}-\mathrm{NMR}\left(\mathrm{CDCl}_{3}\right): \delta 21.1,26.8,29.5,40.7$, $120.3,123.4,123.5,125.7,140.5,142.7,143.2,145.1$; HRMS (EI) Calc. for $\mathrm{C}_{26} \mathrm{H}_{30}$ : 342.2347. Found: 342.2345 .

Compound 5d: yellow oil (0.006 g, 4\%); IR $\left(\mathrm{CHCl}_{3}\right)$ : 3067, 2961, 1459, $885 \mathrm{~cm}^{-1} ;{ }^{1} \mathrm{H}-\mathrm{NMR}\left(\mathrm{CDCl}_{3}\right): \delta 0.78$ $(\mathrm{d}, J=6.6 \mathrm{~Hz}, 3 \mathrm{H}), 0.81(\mathrm{~d}, J=6.6 \mathrm{~Hz}, 3 \mathrm{H}), 1.18(\mathrm{~d}$, $J=6.9 \mathrm{~Hz}, 3 \mathrm{H}), 1.24(\mathrm{~d}, J=6.9 \mathrm{~Hz}, 3 \mathrm{H}), 1.92(\mathrm{~m}, 1 \mathrm{H})$, 
$2.38(\mathrm{~d}, J=22.5 \mathrm{~Hz}, 1 \mathrm{H}), 2.51(\mathrm{~d}, J=22.5 \mathrm{~Hz}, 1 \mathrm{H})$, $3.00(\mathrm{~s}, 2 \mathrm{H}), 3.12(\mathrm{~m}, 1 \mathrm{H}), 3.45(\mathrm{~d}, J=21.0 \mathrm{~Hz}, 1 \mathrm{H})$, $3.57(\mathrm{~d}, J=21.0 \mathrm{~Hz}, 1 \mathrm{H}), 5.02(\mathrm{br} \mathrm{s}, 1 \mathrm{H}), 5.17$ (br s, $1 \mathrm{H}), 6.87-7.36(\mathrm{~m}, 8 \mathrm{H}) ;{ }^{13} \mathrm{C}-\mathrm{NMR}\left(\mathrm{CDCl}_{3}\right): \delta 17.7$, 18.0, 20.8, 21.0, 26.8, 37.6, 40.1, 41.0, 41.7, 58.9, 108.4, $120.5,123.0,123.1,123.5,124.0,124.4,125.1,126.3$, 126.8, 141.4, 143.8, 144.0, 144.3, 147.5, 153.8; HRMS (EI) Calc. for $\mathrm{C}_{26} \mathrm{H}_{30}: 342.2347$. Found: 342.2347 .

\subsection{1,2-Bis[(3-phenyl)-2-indenyl]ethane (4g)}

To a stirred solution of $\mathrm{TiCl}_{3}(256 \mathrm{mg}, 1.66 \mathrm{mmol})$ in 1,2-dimethoxyethane $(12 \mathrm{ml})$ at $0^{\circ} \mathrm{C}, \mathrm{LiAlH}_{4}(21 \mathrm{mg}$, $0.553 \mathrm{mmol}$ ) was added in one portion. After stirring for $15 \mathrm{~min}$, a solution of 2-(hydroxymethyl)indene (123 $\mathrm{mg}, 0.553 \mathrm{mmol})$ in 1,2-dimethoxyethane $(2 \mathrm{ml})$ was cannulated into the resultant black reaction mixture. Upon gradual warming to r.t. the reaction mixture was refluxed for $48 \mathrm{~h}$. The solution was then cooled to $0^{\circ} \mathrm{C}$ and quenched by addition of $1 \mathrm{M} \mathrm{HCl}$. The layers were separated and the aqueous phase was extracted with EtOAc. The combined organic extract was washed with water, saturated brine, and dried over $\mathrm{Na}_{2} \mathrm{SO}_{4}$. The solvents were removed and the crude product was recrystallized from hot hexanes to give $0.156 \mathrm{~g}(46 \%)$ of bis-indene $\mathbf{4 g}$ as a yellow solid. The mother liquor was concentrated and the residue $(0.122 \mathrm{~g}, 36 \%)$ was determined by ${ }^{1} \mathrm{H}-\mathrm{NMR}$ to contain a 4:5 mixture of $\mathbf{4 g}: \mathbf{5 g}$.

Compound 4g: m.p. $169-171^{\circ} \mathrm{C}$; IR (powder) 3018, 2951, 2901, 1612, 1603, 1491, $1459 \mathrm{~cm}^{-1} ;{ }^{1} \mathrm{H}-\mathrm{NMR}$ $\left(\mathrm{CDCl}_{3}\right): \delta 2.75(\mathrm{~s}, 4 \mathrm{H}), 3.29(\mathrm{~s}, 4 \mathrm{H}), 7.10-7.38(\mathrm{~m}$, $18 \mathrm{H}) ;{ }^{13} \mathrm{C}-\mathrm{NMR}\left(\mathrm{CDCl}_{3}\right): \delta 29.3,40.5,119.6,123.4$, $124.2,126.2,127.0,128.4,129.1,135.5,140.0,142.5$, 143.7, 146.4; HRMS (EI) Calc. for $\mathrm{C}_{32} \mathrm{H}_{26}: 410.2035$. Found: 410.2033.

Compound 5g: ${ }^{1} \mathrm{H}-\mathrm{NMR}\left(\mathrm{CDCl}_{3}\right): \delta 2.70(\mathrm{~d}, J=23.0$ $\mathrm{Hz}, 1 \mathrm{H}), 2.88(\mathrm{~d}, J=23.2 \mathrm{~Hz}, 1 \mathrm{H}), 3.40(\mathrm{~d}, J=14.3$ $\mathrm{Hz}, 1 \mathrm{H}), 3.44$ (d, $J=20.3 \mathrm{~Hz}, 1 \mathrm{H}), 3.50(\mathrm{~d}, J=14.0$ $\mathrm{Hz}, 1 \mathrm{H}), 3.57$ (d, $J=20.3 \mathrm{~Hz}, 1 \mathrm{H}), 4.73$ (app. t, $J=2.3$ $\mathrm{Hz}, 1 \mathrm{H}), 5.01$ (app. t, $J=2.0 \mathrm{~Hz}, 1 \mathrm{H}), 6.81-7.37$ (m, $18 \mathrm{H})$.

\subsection{4. rac-and meso-Ethylene bis $\left[\eta^{5}-4,5,6,7-1\right.$-tetra- hydro(5-methyl)-2-indenyl] titanium dichloride $(\boldsymbol{8 b}, \mathbf{9 b})$}

To a degassed solution of 1,2-bis[(5-methyl)-2-indenyl]ethane (4b) $(0.067 \mathrm{~g}, 0.23 \mathrm{mmol})$ in THF (3 ml) at $-70^{\circ} \mathrm{C}, n$-BuLi $(0.19 \mathrm{ml}$ of a $2.5 \mathrm{M}$ solution in hexanes, $0.47 \mathrm{mmol}$ ) was added dropwise. After stirring for $1 \mathrm{~h}, \mathrm{TiCl}_{3} \cdot(\text { thf })_{3}(0.088 \mathrm{~g}, 0.24 \mathrm{mmol})$ was added. The resultant dark red reaction mixture was then allowed to reach r.t. followed by refluxing for $4 \mathrm{~h}$. After gradual cooling to r.t. and to $-40^{\circ} \mathrm{C}, \mathrm{HCl}(6 \mathrm{M}, 1.5 \mathrm{ml}, 9.2$ mmol) was added. Dry air was gently bubbled through the reaction mixture while warming to r.t. for $1 \mathrm{~h}$. The reaction mixture was extracted with $\mathrm{CH}_{2} \mathrm{Cl}_{2}$ and the organic layer was dried $\left(\mathrm{Na}_{2} \mathrm{SO}_{4}\right)$. The solvents were removed and the crude product was dissolved in THF $(2 \mathrm{ml}) . \mathrm{PtO}_{2}(0.001 \mathrm{~g}, 0.005 \mathrm{mmol})$ was added and the reaction mixture was placed under $\mathrm{H}_{2}$ atmosphere. After stirring for $48 \mathrm{~h}$, the reaction mixture was filtered through Celite and the removal of solvents gave $0.004 \mathrm{~g}$ $(36 \%)$ of a mixture of racemic (8b) and meso (9b) ansa-titanocenes. The diastereomeric ratio was not readily determined by spectroscopic techniques because of the inherent similarities between the two stereoisomers. The crude product was characterized by its ${ }^{1} \mathrm{H}$ NMR spectrum: ${ }^{1} \mathrm{H}-\mathrm{NMR}\left(\mathrm{CDCl}_{3}\right): \delta 1.05(\mathrm{~d}, J=6.3$ $\mathrm{Hz}, 6 \mathrm{H}), 1.60-1.74(\mathrm{~m}, 4 \mathrm{H}), 2.46-2.62(\mathrm{~m}, 4 \mathrm{H}), 2.83-$ $3.04(\mathrm{~m}, 4 \mathrm{H}), 3.11(\mathrm{~s}, 4 \mathrm{H}), 5.48(\mathrm{~s}, 1 \mathrm{H}), 5.49(\mathrm{~s}, 1 \mathrm{H})$, $5.54(\mathrm{~s}, 1 \mathrm{H}), 5.55(\mathrm{~s}, 1 \mathrm{H})$. Recrystallization from $\mathrm{CH}_{2} \mathrm{Cl}_{2}$ /hexane (1:2) gave meso ansa-titanocene $\mathbf{9 b}$ as a red solid. IR $\left(\mathrm{CHCl}_{3}\right)$ : 2956, 2923, 1514, 1447, 1419, $1376 \mathrm{~cm}^{-1} ;{ }^{1} \mathrm{H}-\mathrm{NMR}\left(\mathrm{CDCl}_{3}\right): \delta 1.05\left(\mathrm{CHCH}_{3}, \mathrm{~d}\right.$, $J=6.3 \mathrm{~Hz}, 6 \mathrm{H}), 1,60-1.74(\mathrm{~m}, 6 \mathrm{H}), 2.46-2.62$ (m, 4H), 2.83-3.04 (m, 4H), $3.11(\mathrm{~s}, 4 \mathrm{H}), 5.48(\mathrm{Cp}-\mathrm{H}, \mathrm{s}, 1 \mathrm{H})$, $5.49(\mathrm{Cp}-\mathrm{H}, \mathrm{s}, 1 \mathrm{H}), 5.54(\mathrm{Cp}-\mathrm{H}, \mathrm{s}, 1 \mathrm{H}), 5.55(\mathrm{Cp}-\mathrm{H}$, $\mathrm{s}, 1 \mathrm{H}) ;{ }^{13} \mathrm{C}-\mathrm{NMR}\left(\mathrm{CDCl}_{3}\right): \delta 22.2,26.0,29.6,30.1$, $31.0,33.1,111.1,113.5,137.4,137.5,137.8$.

\subsection{5. rac-Ethylene bis $\left[\eta^{5}-4,5,6,7-1-(2-m e t h y l p r o p y l)-\right.$ tetrahydro-2-indenyl] titanium dichloride $(\boldsymbol{8 c})$}

The preparation of $\mathbf{8 c}$ was accomplished according to the procedure for ethylene bis[tetrahydro-(5-methyl)-2indenyl] titanium dichloride: $0.22 \mathrm{~g}$ of $\mathbf{4 c}(0.60 \mathrm{mmol})$ was treated with $\mathrm{TiCl}_{3} \cdot(\text { thf })_{3}$ to afford a crude mixture of $8 \mathbf{c}$ and $9 \mathrm{c}(0.26 \mathrm{~g}, 88 \%)$ with a $4: 1$ ratio as determined by ${ }^{1} \mathrm{H}-\mathrm{NMR}$. Recrystallization from $\mathrm{CH}_{2} \mathrm{Cl}_{2} /$ hexane (1:2) gave pure racemic ansa-titanocene $8 \mathbf{c}$ as a bright red solid, m.p. $271-272^{\circ} \mathrm{C}$; IR $\left(\mathrm{CHCl}_{3}\right)$ : 2949 , 1558, 1506, $1456 \mathrm{~cm}^{-1}$; ${ }^{1} \mathrm{H}-\mathrm{NMR}\left(\mathrm{CDCl}_{3}\right): \delta 0.86$ $\left(\mathrm{CH}\left(\mathrm{CH}_{3}\right)_{2}, \mathrm{~m}, 12 \mathrm{H}\right), 1.58-1.76(\mathrm{~m}, 4 \mathrm{H}), 1.81-1.92(\mathrm{~m}$, $4 \mathrm{H}), 2.19(\mathrm{~m}, 2 \mathrm{H}), 2.44(\mathrm{~m}, 4 \mathrm{H}), 2.87(\mathrm{~d}, J=8.4 \mathrm{~Hz}$, 2H), $3.07(\mathrm{~m}, 4 \mathrm{H}), 3.26(\mathrm{~d}, J=9 \mathrm{~Hz}, 2 \mathrm{H}), 3.87(\mathrm{t}$, $J=5.7 \mathrm{~Hz}, \quad 4 \mathrm{H}), \quad 5.14 \quad(\mathrm{Cp}-\mathrm{H}, \quad \mathrm{s}, \quad 2 \mathrm{H}) ;{ }^{13} \mathrm{C}-\mathrm{NMR}$ $\left(\mathrm{CDCl}_{3}\right): \delta 21.9,22.3,22.4,22.9,24.1,25.5,28.0,30.1$, 36.7, 107.1, 131.3, 133.5, 134.9, 139.2; HRMS (FAB) Calc. for $\mathrm{C}_{28} \mathrm{H}_{40} \mathrm{TiCl}_{2}$ : 494.1986. Found: 494.2011.

\subsection{6. rac-Ethylene bis[ $\eta^{5}-4,5,6,7-1-(1-m e t h y l e t h y l)-$ tetrahydro-2-indenyl] titanium dichloride $(\boldsymbol{8 d})$}

The preparation of $\mathbf{8 d}$ was accomplished according to the procedure for ethylene bis[tetrahydro-(5-methyl)-2indenyl] titanium dichloride: $0.022 \mathrm{~g}$ of $\mathbf{4 d}(0.06 \mathrm{mmol})$ was treated with $\mathrm{TiCl}_{3} \cdot(\text { thf })_{3}$ to afford a crude mixture of $8 \mathbf{d}$ and $9 \mathbf{d}(0.021 \mathrm{~g}, 76 \%)$ with a $2: 1$ ratio as determined by ${ }^{1} \mathrm{H}-\mathrm{NMR}$. Recrystallization from $\mathrm{CH}_{2} \mathrm{Cl}_{2} /$ hexane gave pure racemic ansa-titanocene $8 \mathbf{d}$ as a red solid, IR $\left(\mathrm{CHCl}_{3}\right)$ : 2955, 1457, $817 \mathrm{~cm}^{-1} ;{ }^{1} \mathrm{H}-\mathrm{NMR}$ $\left(\mathrm{CDCl}_{3}\right): \delta 0.98\left(\mathrm{CH}\left(\mathrm{CH}_{3}\right)_{2}, \mathrm{~d}, J=7.2 \mathrm{~Hz}, 6 \mathrm{H}\right), 1.09$ 
$\left(\mathrm{CH}\left(\mathrm{CH}_{3}\right)_{2}, \mathrm{~d}, J=6.9 \mathrm{~Hz}, 6 \mathrm{H}\right), 1.43-1.62(\mathrm{~m}, 4 \mathrm{H})$, $1.78-1.86(\mathrm{~m}, 4 \mathrm{H}), 2.29-2.50(\mathrm{~m}, 4 \mathrm{H}), 2.88(\mathrm{~d}, J=9.6$ $\mathrm{Hz}, 2 \mathrm{H}), 2.94-3.05(\mathrm{~m}, 6 \mathrm{H}), 3.37(\mathrm{~d}, J=9.6 \mathrm{~Hz}, 2 \mathrm{H})$, $5.24(\mathrm{Cp}-\mathrm{H}, \mathrm{s}, 2 \mathrm{H}) ;{ }^{13} \mathrm{C}-\mathrm{NMR}\left(\mathrm{CDCl}_{3}\right): \delta 21.8,22.2$, 24.4, 26.0, 28.1, 28.9, 38.7, 109.8, 126.3, 132.8, 134.7, 138.0; HRMS (FAB) Calc. for $\mathrm{C}_{26} \mathrm{H}_{36} \mathrm{TiCl}_{2}: 466.1673$. Found: 466.1678.

\subsection{7. rac-Ethylene bis $\left(\eta^{5}-4,5,6,7-1\right.$-benzyl-tetrahydro-2- indenyl) titanium dichloride $(\boldsymbol{8} \boldsymbol{e})$}

The preparation of $\mathbf{8 e}$ was accomplished according to the procedure for ethylene bis[tetrahydro-(5-methyl)-2indenyl] titanium dichloride: $0.25 \mathrm{~g}$ of $4 \mathrm{e}(1.07 \mathrm{mmol})$ was treated with $\mathrm{TiCl}_{3} \cdot(\text { thf })_{3}$ to afford a crude mixture of $8 \mathrm{e}$ and $9 \mathrm{e}(0.039 \mathrm{~g}, 74 \%)$ with a $3.6: 1$ ratio as determined by ${ }^{1} \mathrm{H}-\mathrm{NMR}$. Recrystallization from $\mathrm{CH}_{2} \mathrm{Cl}_{2} /$ hexane gave pure racemic ansa-titanocene $\mathbf{8 e}$ as a red solid, m.p. $325^{\circ} \mathrm{C}$ (dec.); IR $\left(\mathrm{CHCl}_{3}\right)$ : 3088, 2937, 1600, 1507, $1492 \mathrm{~cm}^{-1} ;{ }^{1} \mathrm{H}-\mathrm{NMR}\left(\mathrm{CDCl}_{3}\right): \delta 1.56(\mathrm{~m}$, $4 \mathrm{H}), 1.68-1.80(\mathrm{~m}, 2 \mathrm{H}), 1.84-1.94(\mathrm{~m}, 2 \mathrm{H}), 2.45(\mathrm{~m}$, 2H), $2.78(\mathrm{~m}, 2 \mathrm{H}), 3.05-3.20(\mathrm{~m}, 6 \mathrm{H}), 3.35(\mathrm{~m}, 2 \mathrm{H}), 3.49$ $\left(\mathrm{PhCH}_{2} \mathrm{Cp}, \mathrm{d} J=16 \mathrm{~Hz}, 2 \mathrm{H}\right), 3.63(\mathrm{PhCH} 2 \mathrm{Cp}, \mathrm{d}, J=16$ $\mathrm{Hz}, 2 \mathrm{H}), 5.33(\mathrm{Cp}-\mathrm{H}, \mathrm{s}, 2 \mathrm{H}), 7.01(\mathrm{~d}, J=7.4 \mathrm{~Hz}, 4 \mathrm{H})$, 7.16-7.29 (m, 6H); ${ }^{13} \mathrm{C}-\mathrm{NMR}\left(\mathrm{CDCl}_{3}\right): \delta 21.8,22.1$, 23.9, 25.5, 27.9, 33.0, 107.4, 126.2, 128.0, 128.5, 129.1, 134.1, 135.7, 139.6, 139.8; HRMS (FAB) Calc. for $\mathrm{C}_{34} \mathrm{H}_{36} \mathrm{TiCl}_{2}\left[M^{+}-\mathrm{Cl}\right]$ : 527.1985. Found: 527.1950.

\section{Supplementary material}

Further details of the crystal structure investigations are available on request from the Cambridge Crystallographic Data Centre, where the CCDC numbers are as follows: 8c CCDC 104502; 8d CCDC 104503; 9b CCDC 104504. Copies of this information may be obtained free of charge from The Director, CCDC, 12 Union Road, Cambridge, CB2 1EZ, UK (Fax: + 44-1223-336-033; e-mail: deposit@ccdc.cam.ac.uk or www: http:// www.ccdc.cam.ac.uk).

\section{Acknowledgements}

The authors thank Bernd Steinmetz for assistance with the preparation of ansa-titanocenes $\mathbf{8 b}$ and $\mathbf{9 b}$. Supporting information available: tables of X-ray crystallographic data for compounds $8 \mathbf{c}-\mathbf{d}$ and $\mathbf{9 b}$ (27 pages).

\section{References}

[1] (a) J.F. Harrod, K. Rahimian, Inorg. Chim. Acta 270 (1998)
330. (b) N.M. Heron, J.A. Adams, A.H. Hoveyda, J. Am. Chem. Soc. 119 (1997) 6205. (c) F.A. Hicks, S.L. Buchwald, J. Am. Chem. Soc. 118 (1996) 11688. (d) B.A. Kuntz, R. Ramachandran, N.J. Taylor, J. Guan, S. Collins, J. Organomet. Chem. 497 (1995) 133. (e) M.B. Carter, B. Schiott, A. Gutierrez, S.L. Buchwald, J. Am. Chem. Soc. 116 (1994) 11667. (f) R.L. Halterman, T.M. Ramsey, Z.Z. Chen, J. Org. Chem. 59 (1994) 2642. (g) C.A. Willoughby, S.L. Buchwald, J. Am. Chem. Soc. 116 (1994) 11703. (h) R.D. Broene, S.L. Buchwald, J. Am. Chem. Soc. 115 (1993) 12569. (i) S.L. Colletti, R.L. Halterman, Tetrahedron Lett. 33 (1992) 1005.

[2] R.L. Halterman, Chem. Rev. 92 (1992) 965.

[3] S.R. Hitchcock, J.J. Situ, J.A. Covel, M.M. Olmstead, M.H. Nantz, Organometallics 14 (1995) 3732.

[4] (a) R.L. Halterman, T.L. Ramsey, Organometallics 12 (1993) 2879. (b) W.W. Ellis, T.K. Hollis, W. Odenkirk, J. Whelan; R. Ostrander, A.L. Rheingold, B. Bosnich, Organometallics 12 (1993) 4391.

[5] (a) F.R.W.P. Wild, L. Zsolnai, G. Huttner, H.H. Brintzinger, J. Organomet. Chem. 232 (1982) 233. (b) R.B. Grossman, R.A. Doyle, S.L. Buchwald, Organometallics 11 (1991) 1501.

[6] W. Spaleck, M. Antberg, V. Dolle, R. Klein, J. Rohrmann, A. Winter, New J. Chem. 14 (1990) 499.

[7] For related fulvene-coupling approaches to ansa-metallocenes, see: (a) P. Burger, K. Hortmann, J. Deibold, H.H. Brintzinger, J. Organomet. Chem. 417 (1991) 9. (b) S. Collins, Y. Hong, N.J. Taylor, Organometallics 9 (1990) 2695. (c) S. Gutmann, P. Burger, H.U. Hund, J. Hofmann, H.H. Britzinger, J. Organomet. Chem. 369 (1989) 343. (d) H. Schwemlein, H.H. Britzinger, J. Organomet. Chem. 254 (1983) 69.

[8] M.H. Nantz, S.R. Hitchcock, S.C. Sutton, M.D. Smith, Organometallics 12 (1993) 5012.

[9] (a) J.E. McMurry, M.J. Silvestri, Org. Chem. 40 (1975) 2687. (b) K.B. Sharpless, R.P. Hanzlik, E.E. van Tamelen, J. Am. Chem. Soc. 90 (1968) 209. (c) Y.-H. Lai, Org. Prep. Proc. Int. 12 (1980) 363. (d) M. Sato, K. Oshima, Chem. Lett. (1982) 157.

[10] H. Palandoken, W.T. McMillen, M.H. Nantz, Org. Prep. Proc. Int. 28 (1996) 702.

[11] Compounds $3 \mathbf{c}-\mathbf{e}$ are obtained as inseparable mixtures of indenyl double bond isomers at positions C(1)-(3). Treatment with triethylamine at reflux gives the depicted isomers.

[12] A.G. Myers, N.J. Tom, M.E. Fraley, S.B. Cohen, D.J. Madar, J. Am. Chem. Soc. 119 (1997) 6072.

[13] G. Maiti, S.C. Roy, Tetrahedron Lett. 38 (1997) 495.

[14] L.E. Manzer, Inorg. Synth. 21 (1982) 135.

[15] S.C. Collins, Y. Hong, R. Ramachandran, N.J. Taylor, Organometallics 10 (1991) 2349.

[16] M.M. Olmstead, S.R. Hitchcock, M.H. Nantz, Acta Crystallogr. C52 (1996) 1523.

[17] Hydrogenation of the previously reported (Ref. [3]) racemic, benzyl-substituted, 2-(indenyl) ansa-titanocene afforded the reference sample of rac -8e.

[18] To our knowledge there are no other examples of $\alpha$-phenyl ansa-titanocenes.

[19] In the ${ }^{1} \mathrm{H}-\mathrm{NMR}$ spectrum of a rac:meso mixture, the meso $4 \mathrm{H}$ multiplet for an $\alpha$-substituted ethano-bridged ansa-titanocene is typically observed between the chemical shifts of the two racemic $2 \mathrm{H}$ multiplets.

[20] G.M. Sheldrick, SHELXs. Program for the solution of crystal structures, Acta Crystallogr. A46 (1990) 467.

[21] G.M. Sheldrick, SHELXL-97. Program for the refinement of crystal structures, University of Göttingen, Germany, 1997.

[22] S.R. Parkin, B. Moezzi, H. Hope, J. Appl. Cryst. 28 (1995) 53.

[23] O. Bortolini, S. Campestrini, F. Di Furia, G. Modena, J. Org. Chem. 52 (1987) 5093. 